\title{
Transmigration Policy in the Context of Autonomy Era in East Kalimantan
}

\author{
Purwaningsih $^{1}$, Dusadee Ayuwat ${ }^{2}$, Jaggapan Cadchumsang ${ }^{3}$ \\ 'Sociology Department, Faculty of Humanities and Social Sciences, Khon Kaen University, Thailand (email: \\ purwaning02@gmail.com), ${ }^{2}$ Sociology Department, Faculty of Humanities and Social Sciences, Khon Kaen \\ University, Thailand (email: purwaning02@gmail.com), ${ }^{3}$ Sociology Department, Faculty of Humanities and Social \\ Sciences, Khon Kaen University, Thailand
}

\begin{abstract}
Transmigration in Indonesia is perceived as an important approach to improve welfare; however, this policy has also been a subject of criticism. Along with the enactment of the Regional Autonomy Law, the transmigration policy changed from centralized to decentralize. That is, the regional government has a large role in making decisions on the implementation of transmigration. The national transmigration program was rejected in several transmigration destinations in Indonesia. Nevertheless, transmigration is still recognized as one of the programs that can improve people's living standards and one of the ways to develop the region. This paper discusses the role of transmigration in the development process in East Kalimantan Province and various issues related to interactions between local communities and transmigration communities as migrants. The sources of data and information in this paper are reviews of various research reports, journal articles, books, and other supporting documents.
\end{abstract}

\section{Keywords:}

East Kalimantan; the autonomy era; the early Otonomy era; decentra Sociology Department, Faculty of Humanities and Social Sciences, Khon Kaen University, Thailand lization; centralization.

\section{Introduction}

In the context of regional development in Indonesia, the implementation of transmigration as government policy plays an important role. The impact of population displacement held by the government directly affects the economy. Through the transmigration of economic mechanisms took place because the displacement of the population between regions was assumed by the interaction between supply and demand of residents. In this case, the population is a human.

Formally, the province of East Kalimantan is a region with a small population (SUPAS, 2015). Therefore, the Government of Indonesia made this province as the destination location for transmigration. East Kalimantan Province officially became the 
destination area of Transmigration since 1954. The first number of Transmigration families stationed in the province of East Kalimantan was 1.508 family heads. The placement of trans-migrants in the province of East Kalimantan took place in two phases: (1) from 1954 to 2010 and (2) again starting in 2018. That is, in East Kalimantan province, from 2011 to 2017, there are no trans-migrants placement originating from other provinces or islands from Indonesia. Total population transfer in East Kalimantan province 71.367 head of the family (Disnakertrans, 2019).

Transmigration in the era of its regional autonomy can be divided into two parts. First, the implementation of transmigration in the early era of regional autonomy is still characterized by a centralized because it is still under law No. 15 of 1997 on Transmigration. Second, the implementation of transmigration after the enactment of law No. 29 of 2009 about the amendment of law No. 15 of 1997 on Transmigration. The implementation of transmigration in the second part is the implementation of decentralization. A decentralized is a source for the renewal of the transmigration program. In the sense of decentralization leads to shifting authority on transmigration. In the era of the regional government, autonomy has a major role in the implementation of transmigration, so it is with indigenous peoples as landowners of Ulayat (customary land). Both groups had a relationship in the decision making of transmigration.

This paper will discuss the role of transmigration in the development of the province of East Kalimantan and examine issues related to the interaction between local communities and the transmigrant community as migrants.

The study of transmigration in the era of regional autonomy was provided by Junaidi, Rustiadi, Sutomo, and Juanda (2012). They argue that the study of transmigration of the regional autonomy era still has not much focus on the knowledge after the coaching period (between 5 to 6 years) and after being the definitive village. Previous transmigration studies tend to illustrate the development performance of transmigration during the construction period, i.e. after placement of up to 5 or 6 years. This condition results in difficulties in obtaining information about what is happening after the construction process. Likewise, there is difficulty to assess the sustainability of success or the failure of transmigration development. 
According to Yuminarti (2017), the difference in the definition of transmigration based on regulations before and after the regional autonomy Era is related to the point of view of interest used to make definitions. The definition of transmigration before the regional autonomy Era, the perspective used tends to follow the interests of government governments. Meanwhile, the definition of transmigration after the regional autonomy Era tends to follow the interests of transmigrants. Precisely, the definition of transmigration before the Era of regional autonomy is the removals of the population from one area to settle into another area for the development interests of the country or the reasons deemed necessary by the Government. The definition of transmigration after the regional autonomy Era is more defined on the voluntary displacement of residents to improve welfare and settle in the Transmigration site held by the government.

\section{Methods}

This research was conducted in East Kalimantan province. As the location of the transmigration placement, the province has had a long journey (since 1954). The long journey of Transmigration in East Kalimantan Province is a part of the long journey of transmigration in Indonesia. Chronologically, the transmigration journey in Indonesia is associated with the Government profile (Setiawan, 2010; Dahlan, 2014; Pratiwi, 2016).

This paper uses a descriptive analysis method to describe the facts and conditions as well as the nature of various relationship phenomena in the field. The sources of data and information in this paper are the results of the literature study of various research reports, articles, books and supporting documents, as well as the author's experience when conducting research related to the topic of transmigration.

The method used to support this paper is a descriptive method with the comparative analysis used to compare the implementation of Transmigration program in the early era of regional autonomy and the implementation of the Transmigration program after enactment Law No. 29/2009 in the era of regional autonomy and conditions of socioeconomic of transmigration locations in East Kalimantan. 


\section{Results and Discussion}

East Kalimantan Province was established under Law No. 25/year 1956 as an autonomous Region, and based on BPS data (2017) consists of 7 regencies and 3 municipalities; 103 subdistricts; 834 Village; and 198 Urban Village. The total land area of East Kalimantan Province is 127, 346.92 km2. The boundary of East Kalimantan Province in North Kalimantan in the north, Makasar Strait (Makassar Strait) and the Sulawesi Sea (Sulawesi Sea) in the east, South Kalimantan in the south, and West Kalimantan, Central Kalimantan, and Sarawak in West (BPS, 2018).

In 2018, inhabitants in East Kalimantan province was 3,648,835 inhabitants (BPS, 2019). The island of Kalimantan has sparsely inhabitants (Abdul, 1987; Bappenas, BPS, and UNPF, 2013). It is reflected by the average population density of about 24 peoples per square kilometer (BPS, 2019).

Nevertheless, East Kalimantan Province has relatively many resources, such as land, forest, sea, and river. The provincial position of East Kalimantan is located on the International Sea transportation route as it borders the Strait of Makasar and the Sulawesi Sea is very strategic for international trade. While the topographical condition of East Kalimantan province is dominated by hilly land (73.14 percent of the total region) so the potential for annual crop cultivation activities and conservation areas. While the land is flat up to ramps 26.86 percent of the total region. Land like this is suitable for the cultivation of food crops. The soil type in East Kalimantan region majority of podzolic land suitable for the agricultural business, garden with mixed plant type, vegetable crop, and forest. East Kalimantan Province has 157 rivers large and small, as well as 18 lakes. Season in East Kalimantan there are two namely droughts and rain. The flagship sector of East Kalimantan Province is mining, plantation, and forestry.

Based on the explanation of government regulation No. 56/year 1958 on the fundamentals of the implementation of transmigration is indirectly informed that East Kalimantan province is one of the areas of transmigration destination. Thus, the transmigration program in the East Kalimantan region after the period of Indonesian independence has begun before the enactment of the regulation, namely the year 1954 (Disnakertran, 2013). 
The implementation of Transmigration in East Kalimantan province after the period of independence of Indonesia has lasted from 1954 and last in 2018 (Disnakertrans, 2019). Nevertheless, based on the meeting of the Directorate General of the District and Development settlement of Transmigration (2018), there is a description that East Kalimantan province is one of the provinces that convey the development proposal and Remigration placement in 2019 in the region

As an illustration of the transmigration placement of the old order Era until the regional autonomy Era is shown through table 1.

Table 1.

Placement of transmigration from the old order Era to the regional autonomy Era in East Kalimantan province

\begin{tabular}{|c|l|c|c|}
\hline No & \multicolumn{1}{|c|}{ Era } & $\begin{array}{c}\text { transmigration } \\
\text { settlement } \\
\text { units }\end{array}$ & Amount of households \\
\hline 1 & Old Order (1950-1968) & 17 & 4,733 \\
\hline 2 & New Order (1969-1996) & 172 & 277,246 \\
\hline 3 & Area Autonomy (1997- 2018): & 41 & 8,738 \\
\hline & The early area autonomy (1997-1999) & 7 & 5,733 \\
\hline & The area autonomy (2000 - 2018) & 3 & 3,005 \\
\hline
\end{tabular}

Source: Regional Office of Manpower and Transmigration Department, 2019.

The Transmigration Program, which was conducted after Indonesia's independence in East Kalimantan province, passed the old order Era, New order, and regional autonomy. In the implementation of the transmigration in the old order Era the Committee was formed in 1948, but the first departure of Transmigration was held in 1950. The organizers of the transmigration program are the transmigration offices under the auspices of the Ministry of Labour and Social. In the old order Era, the purpose of transmigration was aligned with political objectives. It was because the old order government was busy defending the independence and improving the economy. The legal basis for the transmigration of the old order Era is Government Regulation (PP) No. 56/year 1958, then confirmed with the government regulation of the Substitute Law (PERPU) No. 29/year 1960 on the fundamentals of the implementation of transmigration Which mentions that the purpose of transmigration in the era of the old order is to improve the security, prosperity, and welfare of the people, as well as to strengthen the sense of unity and unity of the nation by opening natural resources and cultivated the land; Reduce population density by populating population in sparsely populated areas. The statement suggests that 
Transmigration has political objectives in addition to demographic objectives. Although the purpose of transmigration refers to the prosperity and welfare of the people associated with economic objectives, the goal is not yet fully implemented. The important change in the transmigration policy of the old order era is the Government of the Republic of Indonesia, in this case, the government of President Sukarno, explicitly relocated the population to meet the political objectives. The transmigration policy becomes a part of the country's strategic policy to reduce potential social and political tensions. On the other hand, transmigration is regarded as a tool to diffuse the population of different ethnic groups to form a homogeneous cultural identity and enhance national integration. The categories of oldorder era transmigration formally consist of General transmigration, Special transmigration, regional transmigration, and spontaneous transmigration.

General transmigration is the transmigration of the dense I-level areas to Another level I areas hosted by the government. Special transmigration is the transmigration of one area of level I to another level I region with the organizer of the relevant autonomous region. The regional transmigration is transmigration within the area of one level I area organized by the area. Spontaneous transmigration is transmigration that takes place on its own business than it is concerned.

In the era of the old order, East Kalimantan Province provides a location of transmigration in the area of Balikpapan, Samarinda, Penajam Paser Utara, Kutai Kartanegara, and West Kutai. This type of transmigration in the majority of this era is spontaneous transmigration stationed in West Kutai Regency. The second type of transmigration is General transmigration with the location of the placement in $\mathrm{t}$ Samarinda, Balikpapan, Kutai Kartanegara, and Penajam Paser Utara. The third type of transmigration is special transmigration i.e. transmigration of SOB (Staat van Oorlog en Belig) prisoners. They were stationed in Samarinda and Kutai Kartanegara. These transmigrants were transferred to become farmers who manage their land.

Transmigration in the New Order Era is organized by the Department of Transmigration and Cooperatives with the orientation of demographic transmigration development. The legal basis for the implementation of such transmigration is Law No. 3/year 1972 concerning the basic provisions of transmigration and Government Regulation (PP) No. 42/year 1973 on the implementation of transmigration. In line with a change of 
view of the orientation of transmigration development, there have been changes in the transmigration organizers. When the orientation of the development of transmigration is not only the distribution of population but has been programmed towards linkage with regional development programs and other sector development then the Institute of Transmigration organizers is the Department of Labor, Transmigration, and cooperatives. At this stage, there is the development of transmigration "Bedol Deso" which is the displaced population because it is exposed to development projects. Besides, the implementation of transmigration began to be well-organized because of coordination between related agencies. When the orientation of transmigration development shifts from social to the economic aspect, the transmigration is handled by the Ministry of Manpower and Transmigration. The transmigration organizers further changed in 1983 because it became its department of the Transmigration department. During its department, the orientation of transmigration development is directed to the improvement of the quality of the transmigration settlements and develop other business patterns besides food crops such as industrial plants, PIR plantation, industrial services, Fisheries, livestock, and the abrogation of cooperation with the private sector. Another change that occurs is related to the project funding policy which once occurred three years of budget to be a valid one year budget. When the orientation of transmigration development continues to continue agriculture and further improve the pattern of the plantation, fisheries, and industrial plantation, the transmigration implementation is the responsibility of the Department of Transmigration Development. The orientation of transmigration development is again changing towards supporting regional development, expanding the spread of population and labor, improving the welfare of the transmigrants and society in general, and strengthening unity and unity of the nation. At this stage, there is a type of transmigration called Swakarsa Mandiri transmigration (TSM).

Transmigration in the New Order Era is regarded as an important policy because it can be a tool to accelerate the process of national integration. Therefore, the transmigration policy has an important role in the provision of human resources and placement in areas that are sparsely populated so as to support defense and security in the region of Indonesia. The transmigration program in the New Order Era is one of the government's mainstays programs. 
The purpose of transmigration is not solely for the transfer of the population but also focuses on food self-sufficiency. It has consequences of opening the transmigration area then expanded; Reached the peak of success and gained support from the government of Indonesia, the World Bank, the Asian Development Bank, and Western countries..

In the era of the new order are known two categories of transmigration, namely General transmigration and spontaneous transmigration. General transmigration is the displacement of the population that all the costs borne by the Government and given facilities in the form of two hectares, houses, and agricultural equipment and the cost of the first 12 months for the region, the first 8 months in Paddy fields. The allowance for transmigrants is borne by the Government. While spontaneous transmigration is a displacement of population organized from the originating region to the destination by the government, the fare is borne by the transmigration participants.

The location of transmigration resettlement of the new Order Era in East Kalimantan province is scattered in the area of Samarinda, Penajam Paser Utara, Paser, East Kutai, Kutai Kartanegara, West Kutai, Berau, and Balikpapan. While the type of transmigration in East Kalimantan Province in the New Order Era is General transmigration, the Trans Forest crop industry, spontaneous transmigration, and PIR-Trans.

The implementation of transmigration in the era of regional autonomy was laid as components of regional development and regional development. Therefore, the Transmigration program is not only demographics but also has a purpose for regional development. The methods applied are no longer centralized and top-down from the central government, but rather based on inter-regional cooperation. Also, the locals were given a great opportunity to become transmigrants with a portion of up to 50 percent, which could even be more than 50 percent.

The enforcement of law No. 22/year 1999 which was then refined by law No. 32/year 2004; and law No. 25/year 1999; and regulation of the government of INDONESIA No. 25/year 2000 marked the change of authority between central and local governments. This condition also changes the paradigm in conducting transmigration.

Paradigm Change at the transmigration policy level affects the implementation of transmigration in the area, including in the province of East Kalimantan. The placement of transmigration in the province of East Kalimantan in the regional autonomy Era used a 
comparative pattern of 50 percent of the indigenous or immigrant population and 50 percent of the local population or local population. Also, the Province of East Kalimantan adopted a comparison of 60 to 70 percent of the indigenous population and 30 to 40 percent of local population. In the Era of regional autonomy, the provincial government of East Kalimantan placed Transmigrants in Berau Regency, West Kutai Regency, Kutai Kartanegara Regency, East Kutai Regency, Paser regency. The transmigrants are working on a pattern of wetland food crops (TPLB), dry land food crops (TPLK), and plantations.

Related to the method of cooperation between regions that is applied to the implementation of the transmigration of the regional autonomy Era, the provincial government of East Kalimantan established a cooperation agreement with the province of East Java, West Java, Banten, Bali, Nusa Tenggara Timur, Nusa Tenggara Barat, Jogyakarta, Central Java, and Lampung.

The implementation of the regional autonomy Era transmigration in East Kalimantan province is based on law No 15/year 1997, Act No. 29/year 2009, and government regulation No. 3/year 2014. According to law No. 15/year 1997 it contains information that the Transmigration program is positioned as an integral part of national development. Therefore, the law mentions that the main purpose of the Transmigration program is to improve the welfare of the transmigrants and surrounding communities, to improve and detail regional development, and to strengthen unity and Unity of the Indonesian nation. In other words, the information suggests that the transmigration program is not merely a population transfer but also an effort to develop the region. Thus the law No. 15/year 1997 has not positioned the Transmigration program as part of the regional development. After 12 years later, the law No. 15/year 1997 changed with the enactment of law No. 29/year 2009. The law No. 29/year 2009 informs that in governance there has been a change in the centralized approach to desentralistik by adhered to the autonomy of the Azas. The Desentralistik approach provides greater authority to local governments to carry out governance and development functions, including the responsibility of local governments in the implementation of transmigration. Further implementation of the transmigration of the Era of regional autonomy is confirmed by the enforcement of government regulation No. 3/year 2014. 
Noting the explanation above, the author needs to draw firmly the era boundaries for the study. So far there is a legal basis confusion implemented to assess the implementation of transmigration and further livelihood in the regional autonomy Era. As if the early regional autonomy Era has used a decentralized approach. The rules used are still centralistic. That is, at the beginning of the regional autonomy Era transmigration is still determined by the central government. However, it needs legitimacy from local governments and indigenous peoples and religious figures to reduce potential policy conflicts. The condition will affect the data collected for the sustainability study of the transmigration development conditions.

\section{Conclusion}

Transmigration regulation is made to respond to previous regulations and adjusted to the development of the local situation. Because in general, transmigration programs help governments, both central and regional, in regional development. To achieve these objectives, the integrated system and planning are required to ensure the improvement of the living standards of trans-migrants and surrounding communities.

\section{References}

\section{Books}

Bappenas/ Natrtional Development Planning Agency, BPS/ Central Bureau of statistic, United Nations Population Fund (2013). Indonesia Population Projection. Jakarta. BPS/ Central Bureau of Statistic (2016). Profil penduduk Indonesia hasil SUPAS 2015. Jakarta. BPS/ Central Bureau of Statistic (2017). Provinsi Kalimantan Timur dalam angka 2017. Provinsi Kalimantan Timur.

BPS/ Central Bureau of Statistic (2018). Provinsi Kalimantan Timur dalam angka 2018. Provinsi Kalimantan Timur

BPS/ Central Bureau of Statistic (2019). Provinsi Kalimantan Timur dalam angka 2019. Provinsi Kalimantan Timur.

Disnakertrans/ Regional Office of Manpower and Transmigration Department (2013). Penyelenggaraan Program transmigrasi di Provinsi Kalimantan Timur. Samarinda. 
Disnakertrans/ Regional Office of Manpower and Transmigration Department (2019). Data penempatan transmigrasi di Kalimantan Timur. Samarinda.

\section{Journal article with DOI}

Abdoellah, Oekan Soekotjo (1987). Transmigration Policies in Indonesia: Government Aims and Popular Response. Center for Migration Studies special issues, 5(2), 180 - 196, doi: 10.1111/j.2050-411X.1987.tb00501.x

\section{Journal article retrieved from database without DOI}

Dahlan, M. Halwi (2014). Perpindahan penduduk dalam tiga masa: kolonisasi, kokuminggakari, dan transmigrasi di Provinsi Lampung (1905 - 1979). Patanjala, $\begin{array}{llllll}6(3), & 335 & - & 348 . & \text { Retrieved } & \text { from }\end{array}$ https://www.researchgate.net/publication/323785744_PERPINDAHAN_PENDUDU K_DALAM_TIGA_MASA_KOLONISASI_KOKUMINGGAKARI_DAN_TRANSMI GRASI_DI_PROVINSI_LAMPUNG_1905-1979 .

Junaidi; Rustiadi, Ernan; Sutomo, Slamet; dan Juanda, Bambang (2012). Pengembangan penyelenggaraan transmigrasi di era otonomi daerah: kajian khusus interaksi permukiman transmigrasi dengan desa sekitarnya. Jurnal Visi Publik, 9 (1), 521 534. Retrieved from https://www.researchgate.net/publication/275715055

Pratiwi, Eka Susanti (2016). Perkembangan Islam pada masyarakat transmigrasi di Desa Telang Karya Jalur 8 Jembatan 7 Kec. Muara Telang Kab. Banyuasin (1980 - 2010). Skripsi. Palembang: UIN Raden Fatah. Retrieved from http://eprints.radenfatah.ac.id/178/

Setiawan, Nugraha (2010). Satu abad transmigrasi di Indonesia: perjalanan sejarah pelaksanaan, 1905 - 2005. Bandung: Universitas Padjajaran. Retrieved from http://pustaka.unpad.ac.id/wpcontent/uploads/2009/03/satu_abad_transmigrasi_di_indonesia.pdf .

Yuminarti, Umi (2017). Kebijakan transmigrasi dalam kerangka otonomi khusus di Papua: masalah dan harapan. Jurnal Kependudukan Indonesia, 12(1), 13 - 24. Retrieved from http://ejurnal.kependudukan.lipi.go.id/index.php/jki/article/view/215/pdf 


\section{Website}

Anonim, Peraturan Pemerintah No. 56 tahun 1958 tentang pokok-pokok penyelenggaraan transmigrasi. October,1, 2019, retrieved from https://peraturan.bpk.go.id/Home/Details/76619/pp-no-56-tahun-1958.

Anonim, Peraturan Pemerintah Republik Indonesia No. 3 tahun 2014 tentang pelaksanaan Undang-undang No. 15 tahun 1997 tentang ketransmigrasian sebagaimana telah diubah dengan Undang-undang No. 29 tahun 2009 tentang perubahan atas Undangundang No 15 tahun 1997. October,1, 2019, retrieved from https://webcache.googleusercontent.com/search?q=cache:BvWWftdgQGoJ:https://per aturan.bpk.go.id/Home/Details/65475+\&cd=1\&hl=en\&ct=clnk\&gl=id

Anonim. Penjelasan atas Peraturan Pemerintah Penganti Undang-undang No. 29 / Tahun 1960 tentang pokok-pokok penyelenggaraan transmigrasi. October, 10, 2018, retrieved from https://m.hukumonline.com/pusatdata/detail/18862/node/121/peraturan-pemerintahpengganti-undangundang-nomor-29-tahun-1960/.

Anonim. Undang Undang No. 25 / tahun 1956 tentang pembentukan daerah-daerah otonom Propinsi Kalimantan barat, Kalimantan Selatan, dan Kalimantan Timur. September, 28, 2019, retrieved from https://peraturan.bpk.go.id/Home/Details/51157.

Anonim. Undang-undang No. 29 tahun 2009 tentang perubahan atas Undang- undang No. 15 tahun 1997 tentang ketransmigrasian. April, 20, 2019, retrieved from https://www.atrbpn.go.id/Publikasi/Peraturan-Perundangan/UndangUndang/undang-undang-nomor-29-tahun-2009-893.

Anonim. Undang-undang No. 15/ tahun 1997 tentang Ketransmigrasian. September, 3, 2018 retrieved from https://www.atrbpn.go.id/Publikasi/PeraturanPerundangan/Undang-Undang/undang-undang-nomor-15-tahun-1997-1310. 